\title{
A meta-analysis of the prevalence of Salmonella in food animals in Ethiopia
}

\author{
Getachew Tadesse $^{1^{*}}$ and Tesfaye S Tessema ${ }^{2}$
}

\begin{abstract}
Background: The globalization of the food supply and the increased movements of people, animals and goods have increased the threat of Salmonella infections in several countries. The objective of this study was to estimate the prevalence of Salmonella in food animals in Ethiopia by using meta-analytical methods.

Results: The prevalence of Salmonella in slaughtered cattle, sheep, goats and pigs were $7.07 \%, 8.41 \%, 9.01 \%$ and $43.81 \%$ respectively. The occurrence of Salmonella was significantly higher in pigs than in slaughtered true ruminants $(p<0.001)$ but not significantly different between cattle, sheep and goats $(p>0$. 05). S. Mishmarhaemek, $S$. Infantis and $S$. Hadar were the predominant isolates in cattle, small ruminants and pigs respectively. $S$. Typhimurium was isolated from all host species.

Conclusions: All food animals are considerable reservoirs of Salmonella and pose a significant risk to public health. Safety measures in slaughter houses and butcheries and education of the public could reduce the risk of transmission of Salmonella from animals to humans.
\end{abstract}

Keywords: Animals, Ethiopia, Prevalence, Salmonella, Serotypes

\section{Background}

Globally, non-typhoidal Salmonella (NTS) is a cause of about 155, 000 human deaths each year [1] and the threat of epidemic infections has increased due to the globalization of the food supply and the increased movements of people, animals and goods within and between countries [2,3]. Apart from the morbidity and mortality costs in humans and animals, restrictions to trade and discard of contaminated food are important socioeconomic problems of the bacteria [4].

Humans acquire infection through the consumption of contaminated products or contact with infected animals [5-10]. S. Typhimurium and $S$. Enteritidis are common causes of human diseases [11] and nowadays, the spread of multidrug resistant (MDR) serotypes has become a global concern. For instance, since its description in 2006, in Ethiopia [12], a highly MDR $S$. Kentucky strain has been isolated from domestic and wild animals and humans in Africa, Europe and Asia [13]. Similarly, MDR S. Concord was isolated from Ethiopian adoptees

\footnotetext{
* Correspondence: getadesse1@yahoo.com

${ }^{1}$ Department of Biomedical Sciences, College of Veterinary Medicine and Agriculture, Addis Ababa University, P.O. Box 34, Debra Zeit, Ethiopia Full list of author information is available at the end of the article
}

in Europe and the USA [14,15] and a highly invasive $S$. Typhimurium strain (ST313) has occupied a niche provided by HIV, malaria, and malnutrition in Africa [16]

Ethiopia has the largest animal population in Africa and the living standard of the population is generally favorable for the transmission of pathogens from animals to humans and the vice versa. Despite Salmonellosis being one of the important zoonotic diseases, surveillance and monitoring systems are not in place and the temporal and spatial distributions of the serotypes are not described. The objective of this study was to estimate the prevalence of Salmonella in food animals by using meta-analytical methods.

\section{Methods}

The guideline of the PRISMA group (Preferred Reporting Items for Systematic Reviews and Meta-Analyses) [17] was followed in the reviewing and the check list was used to ensure inclusion of relevant information (see Additional file 1). An animal was considered to be a carrier if Salmonella was detected in the mesenteric lymph nodes (MLN) and/or the gastro-intestinal tract (GIT) contents. A serotype was considered to be dominant if it accounted for more than $5 \%$ of the serotyped isolates in each host group. 


\section{Search and selection of studies}

The search strategy was described in a previous study [18]. Briefly, studies were searched in Medline, Google scholar and the lists of references of articles. The last search was done on September 27, 2014. Eligible studies were selected by using inclusion and exclusion criteria. A study was eligible if it (a) was published in English, (b) was cross sectional, (c) was on apparently healthy animals and (e) described the study design and microbiological methods. Studies with titles and abstracts that were not relevant to the outcomes of interest and studies that did not meet the eligibility criteria or with inappropriate data were excluded.

\section{Data abstraction}

From each eligible study, the first author, year of publication, year of study, location, host species, sampling design, number of animals, microbiological methods, number of Salmonella positive MLN and GIT (small intestinal/caecal/ fecal) content samples were extracted. The study level prevalence ( $\mathrm{p}$ ) and standard error (s.e) were calculated by the following formulae: $p=n p / n$ and s. e. $=\sqrt{ } p(1-p) / n$ : where $n p=$ number of positive samples and $\mathrm{n}=$ number of samples. The data was extracted by TG.

\section{Data analysis}

To produce conservative estimates, a zero reported for the numbers of positive samples was imputed as 0.5 [19]. To normalize the data, the study level estimates were transformed to logit event estimates $[20,21]: \operatorname{lp}=\ln [\mathrm{p} /(1-\mathrm{p})]$, where $\mathrm{lp}=$ the logit event estimate; $\ln =$ the natural logarithm; $\mathrm{p}=$ study level estimate. The variance of the logit event estimates was calculated by the following formula: $v(l p)=1 /(n p)+1 /$ [n $(1-p)]$, where $v=$ variance and $n=$ sample size. The data were grouped and analyzed as ruminant and nonruminant data. A subgroup analysis was done by species of ruminants.

\section{Risks of bias and heterogeneity}

The qualities of the sampling design and the microbiological methods were used to assess the within study biases. A funnel plot was used to get a visual impression of the across study bias (small study effects) of the study level estimates in ruminants. The statistical significance of the bias was assessed by the Egger's regression asymmetry test [22]. The Duval and Tweedie nonparametric 'trim and fill' linear random method was used to calculate unbiased estimates [23].

The heterogeneity of the estimates in ruminants was visually examined by the Galbraith plot [24]. The statistical significance of the heterogeneity was assessed by the Cochran's $\mathrm{Q}$ test and a non significant heterogeneity was accepted if the ratio of $\mathrm{Q}$ and the degree of freedom $(\mathrm{Q} / \mathrm{df})$ was less than one. The inverse variance index $\left(\mathrm{I}^{2}\right)$ was used to quantify the percentage of the variation in prevalence estimates attributable to heterogeneity. $\mathrm{I}^{2}$ values of $25 \%, 50 \%$ and $75 \%$ were considered as low, moderate and high heterogeneity respectively [25].

\section{Pooled estimates}

The DerSimonian and Laird random effects model [26] was used to pool logit event estimates. The pooled logit estimates were back transformed to prevalence estimates (p) by the following formula: $\mathrm{p}=\mathrm{e}^{\mathrm{lp}} /\left(\mathrm{e}^{\mathrm{lp}}+1\right)$ : where $\mathrm{e}=$ the base of the natural logarithm. The sensitivity of the pooled prevalence of Salmonella in ruminants was assessed by single study omitted influence analyses. Whether a pooled estimate is significantly different from zero or not was tested by the $\mathrm{Z}$ test. A study was considered to be influential if the pooled estimate without it was not within the $95 \%$ confidence limits of the overall mean. The Yates corrected Chi Square test was used to test the significance of the differences between pooled estimates [27,28]. Alpha was set at 0.05 .

Microsoft Office Excel 2007 was used to calculate study level prevalence estimates, logit event estimates and standard errors and to transform logit event estimates to prevalence estimates. Epi info ${ }^{\text {tix }}$ (Version 3.5.1, Center for Disease Control, CDC, USA) was used to compare groups. Stata (Version 11.1, Stata Corp, College Station, Texas) was used in all other analyses.

\section{Results and discussion}

\section{Search results and eligible studies}

Figure 1 shows the literature search results. The search yielded 161 reports. One hundred and forty five reports were excluded because the titles and abstracts were not relevant to the outcomes of interests. Of the screened articles, six were excluded due to sampling design, data inconsistency, pooled sample examination, lack of separate information on the number of samples taken from a slaughtering plant and markets, apparently sick and dead animals and small sample size. A total of 10 studies were eligible for quantitative syntheses [29-38].

\section{Characteristics of the eligible studies}

Table 1 depicts the characteristics of the eligible studies. The studies were conducted between 1999 and 2010 in central, Northern and Eastern Ethiopia during the dry and short rainy seasons (October through May). Nine studies were on slaughtered animals and one was on dairy cattle. Whilst most slaughtered ruminants were derived from the extensive production systems in the rural areas, dairy cattle and pigs were from semi-intensive/intensive production systems. A total 3435 MLN and intestinal content samples from 1815 animals (119 camels, 220 goats, 


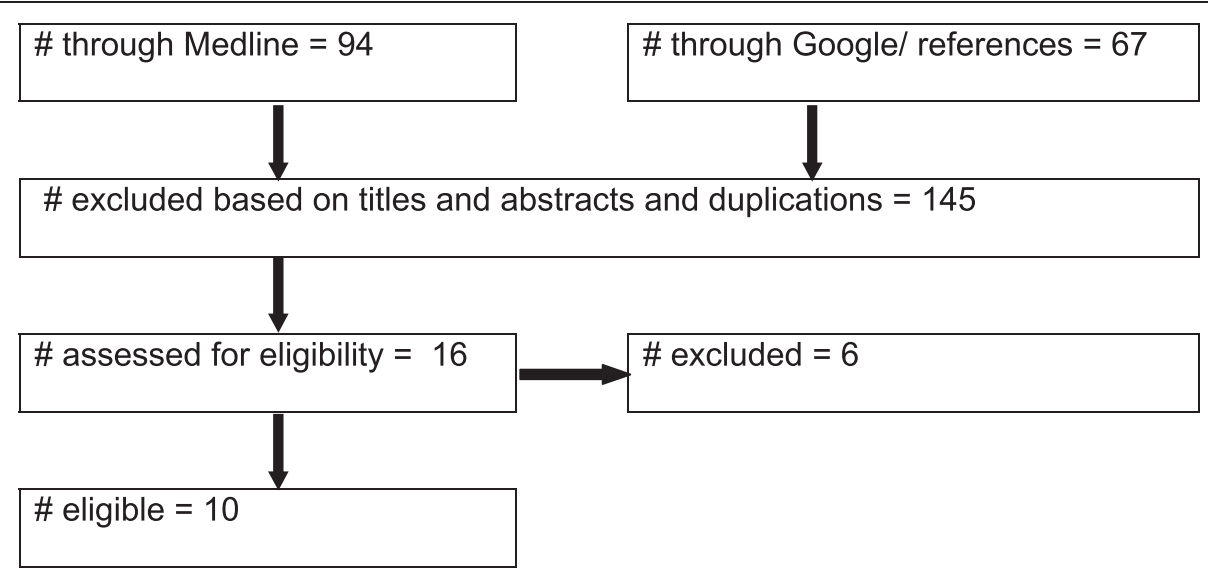

Figure 1 A flow diagram of the selection of studies.

293 sheep, 379 pigs and 804 cattle) were examined to detect Salmonella. The study level estimates ranged from $1.9 \%$ in cattle to $45.5 \%$ pigs.

\section{Risks of bias and heterogeneity}

Sampling was random in seven studies [30-35,37] and all animals presented for slaughter in each sampling day were sampled in three studies [29,36,38]. The analytical units were $25 \mathrm{~g}$ MLN and GIT contents in eight studies [29-31,33,34,36-38], one gram of feces and one milliliter of milk in a study on dairy cattle [32] but not reported in one study [35]. In all studies Salmonella was isolated and identified according to the guideline of the International
Organization for Standardization (ISO 6579, 1998-2002) with some modifications. Both the funnel plot and the Egger's regression asymmetry test did not suggest the presence of bias and the Duval and Tweedie nonparametric method did not incorporate theoretical missing studies. Accordingly, the within and across study biases were considered negligible.

Figure 2 presents forest plots of the untransformed prevalence estimates. The $\mathrm{I}^{2}$ values of the logit event estimates in ruminants and pigs were $81.3 \%$ and Zero respectively. In a subgroup analysis of the ruminant data by host species, the $\mathrm{I}^{2}$ was $39.9 \%$ in sheep, $69.4 \%$ in goats and $89.1 \%$ in slaughtered cattle (Table 2). The moderate to high heterogeneities could be due to several factors

Table 1 Characteristic of the eligible studies

\begin{tabular}{|c|c|c|c|c|c|c|c|}
\hline Author & Host & Sy & Lo & $n$ & $\begin{array}{l}\text { OA } \\
p(\%)\end{array}$ & $\begin{array}{l}\text { GIT } \\
\text { p (\%) }\end{array}$ & $\begin{array}{l}\text { MLN } \\
\text { p (\%) }\end{array}$ \\
\hline [29] & Cattle & $1999 / 2000$ & $\mathrm{DZ}$ & 323 & $6(1.9)$ & $2(0.62)^{a}$ & $4(1.2)$ \\
\hline [30] & Cattle & $2005 / 6$ & $\mathrm{DZ}$ & 100 & $14(14)$ & $6(6)^{b}$ & $8(8)$ \\
\hline$[31]$ & Cattle & $2006 / 7$ & $\mathrm{BD}$ & 186 & $13(7)$ & $11(5.9)^{c}$ & $6(3.2)$ \\
\hline$[32]$ & Cattle & 2010 & $\mathrm{AA}$ & 195 & $21(10.8)$ & $15(7.7)^{a}$ & - \\
\hline [33] & Sheep & $2002 / 3$ & $\mathrm{DZ}$ & 47 & $1(2.1)$ & $1(2.1)^{a}$ & $0(0)$ \\
\hline [34] & Sheep & $2003 / 4$ & AM & 104 & $12(11.5)$ & $5(4.8)^{a}$ & $8(7.7)$ \\
\hline$[35]$ & Sheep & $2007 / 8$ & MJ & 142 & $11(7.8)$ & $3(2.1)^{b}$ & $8(5.6)$ \\
\hline [33] & Goats & $2002 / 3$ & $\mathrm{DZ}$ & 60 & $9(15)$ & $2(3.3)^{a}$ & 7 (11.7) \\
\hline [34] & Goats & $2003 / 4$ & AM & 100 & $3(3)$ & $2(2)^{a}$ & $2(2)$ \\
\hline$[35]$ & Goats & $2007 / 8$ & MJ & 60 & 7 (11.7) & $4(6.7)^{b}$ & $3(5)$ \\
\hline$[36]$ & Pigs & $2004 / 5$ & $\mathrm{AA}$ & 278 & $120(43.2)$ & $63(22.7)^{b}$ & 99 (35.6) \\
\hline [37] & Pigs & $2004 / 5$ & $\mathrm{DZ}$ & 101 & $46(45.5)$ & $17(16.8)^{b}$ & 42 (41.6) \\
\hline [38] & Camels & $2001 / 2$ & DJ & 119 & $28(23.5)$ & $18(15.13)^{a}$ & 19 (15.9) \\
\hline
\end{tabular}

AA, Addis Ababa; AM, Addis Ababa and Modjo; BD, Bahirdar; DZ, Debrezeit; DJ, Diredawa and Jijiga; GIT, gastrointestinal tract; Lo, location; MJ, Modjo; MLN, mesenteric lymph nodes; $n$, number of animals; $p$, number of positive animals; OA, overall animal; Sy, study year.

${ }^{\mathrm{a}}$ Faeces.

${ }^{\mathrm{b}}$ Caecal contents.

'Small intestinal contents. 


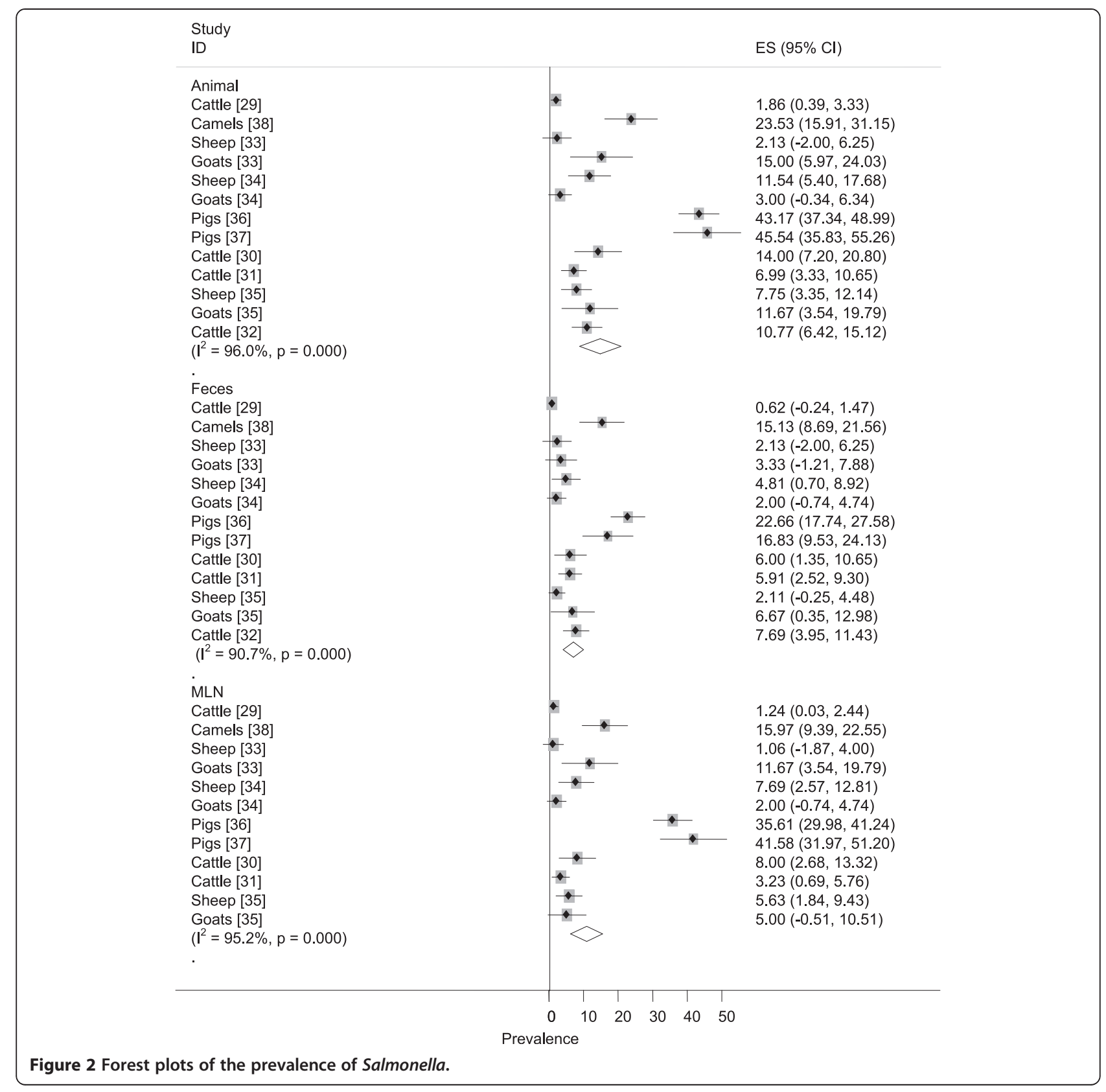

Table 2 Pooled prevalence of Salmonella by host species

\begin{tabular}{|c|c|c|c|c|c|}
\hline \multirow[t]{2}{*}{ Host species } & \multicolumn{2}{|l|}{ Pooled estimate } & \multicolumn{3}{|c|}{ Heterogeneity } \\
\hline & $\mathrm{p}(95 \% \mathrm{Cl})$ & $Z-p$ & $1^{2}$ & Q-p & $\mathrm{Q} / \mathrm{df}$ \\
\hline Ruminants $^{\dagger}$ & $7.47(4.75,11.58)$ & 0.000 & 73.4 & 0.000 & 3.76 \\
\hline Cattle & $7.07(2.05,16.17)$ & 0.000 & 89.1 & 0.000 & 9.17 \\
\hline Sheep & $8.41(4.77,14.42)$ & 0.000 & 39.9 & 0.189 & 1.67 \\
\hline Goats & $9.01(3.88,19.62)$ & 0.000 & 69.4 & 0.038 & 3.27 \\
\hline Pigs & $43.81(38.89,48.85)$ & 0.000 & 0.0 & 0.680 & 0.09 \\
\hline
\end{tabular}

df, degrees of freedom; $I^{2}$, Inverse variance index; Q- $p$, probability value of Cochran's Q test; Z-p, probability value of Z test.

${ }^{\dagger}$ Slaughtered ruminants; all single study omitted pooled estimates were within the $95 \%$ confidence limits of the overall mean. 
including origin of animals, breed, management and exposure to stress. However, the effects of all potential factors but species could not be put in context because of the absence of data and the limited number of studies in further sub groupings.

\section{Pooled prevalence}

The prevalence of Salmonella in slaughtered cattle, sheep, goats and pigs were $7.07 \%, 8.41 \%, 9.01 \%$, and $43.81 \%$ respectively (Table 2). Pooled estimates for camels and dairy cattle were not calculated because each had single reports. Comparison of the estimates with reports elsewhere in Africa is difficult because reports based on national surveys or meta-analytical studies are scarce. However, national survey reports from developed countries show lower fecal/caecal estimates in cattle $(0.2 \%-6.8 \%)$ [39-42], sheep (0.1\%) [39] and pigs (2.5\%-23\%) [39,40,43-46]. In addition, the proportions of Salmonella positive swine production holdings in Europe range from zero in Bulgaria, Sweden, Finland and Norway to $30 \%$ in UK [47]. In Denmark, since the initiation of the control program in 1988/89, the prevalence of Salmonella in poultry and swine has markedly reduced $[48,49]$. In general, there is no set standard and differences across countries could be attributed to several factors that may involve animal, environmental and management factors, control measures and the study methods.

Tables 3 shows pooled prevalence of Salmonella in the MLN and GIT contents by host species. The estimates depict the level of infection in animals and their potential to contaminate animal products, humans, animals and the environment. The relation between humans and animals in Ethiopia is so close to such an extent of sharing the same roof and animal wastes are not properly disposed off. Moreover, the meat handling practice in slaughter houses and butcheries is generally unhygienic [50-52] and backyard slaughtering and raw meat and milk consumption are wide spread practices. In general, the unhygienic living circumstances and lack of awareness of the population on zoonotic diseases are suggestive of the considerable risk associated with the transmission of
Salmonella from animals to humans. Elsewhere, outbreaks through contact with chicks and livestock were reported $[53,54]$.

The prevalence of Salmonella was higher in pigs than in slaughtered ruminants $\left[X^{2}=266.5 ; p<0.001(O R=9.63\right.$ $(95 \% \mathrm{CI}=7.05,13.17)]$ but not significantly different between cattle, sheep and goats ( $p>0.05)$. The occurrence of Salmonella in the MLN was higher in pigs than in slaughtered ruminants $\left[\mathrm{X}^{2}=172.32 ; \mathrm{p}<0.001 ; \mathrm{OR}=11.98(95 \%\right.$ $\mathrm{CI}=7.67,18.81)]$ but not affected by species of slaughtered true ruminants ( $\mathrm{p}>0.05)$. The occurrence of Salmonella in the caecal contents of pigs was significantly higher than the estimate for slaughtered ruminants $\left[X^{2}=72.08\right.$; $\mathrm{p}<0.001$; OR $=6.91(95 \% \mathrm{CI}=4.12,11.68)]$ but not among species of slaughtered true ruminants $(p>0.05)$. The higher occurrence of Salmonella in pigs compared to ruminants is apparently due to the coprophagous feeding behavior and higher exposure of the former to contaminated sources. Therefore, pork is more likely to be contaminated compared to beef, mutton or goat meat and individuals routinely or occupationally exposed to pigs are at a higher risk of acquiring Salmonella than individuals in contact with true ruminants. Similarly, despite a few reports, the risk of acquiring Salmonella from dairy cattle and camels appears higher than the risk from beef cattle, sheep and goats.

\section{Dominant serotypes}

Table 4 depicts the dominant serotypes. Of the 582 Salmonella isolates, 507 were serotyped. Twenty one isolates of dairy cattle [32] and 54 isolates of small ruminants [35] were not serotyped. The numbers of serotypes identified from slaughtered pigs, camel, cattle, sheep and goats were $28,15,15,11$ and 10 respectively. The dominant serotypes isolated from cattle, small ruminants, pigs and camels accounted for $72.46 \%, 67.27 \%, 73.78 \%$ and $81.04 \%$ of the isolates in each group respectively. These serotypes were reported in two or more studies on animals or animal products or humans in Ethiopia: S. Anatum [30,55-60], S. Braenderup [33,38,56-59], $S$. Hadar [33,36,37,56,59], S. Havana [36-38], S. Butantan $[30,38,61]$, S. Heidelberg [31,34,38,62], S. Kentucky

Table 3 Pooled prevalence of Salmonella in the MLN and GIT contents

\begin{tabular}{|c|c|c|c|c|c|c|c|c|c|c|}
\hline \multirow[t]{2}{*}{ Host species } & \multicolumn{5}{|c|}{ Mesenteric lymph node } & \multicolumn{5}{|l|}{ GIT contents } \\
\hline & $\mathrm{p} \mathrm{(95 \%} \mathrm{Cl)}$ & $Z-p$ & $1^{2}$ & $Q-p$ & $\mathrm{Q} / \mathrm{df}$ & $\mathrm{p}(95 \% \mathrm{Cl})$ & $Z-p$ & $1^{2}$ & $Q-p$ & $\mathrm{Q} / \mathrm{df}$ \\
\hline Ruminants $^{\dagger}$ & $4.7(2.88,7.57)$ & 0.000 & 61.8 & 0.007 & 2.62 & $3.66(2.31,5.74)$ & 0.000 & 42.5 & 0.084 & 1.74 \\
\hline Cattle & $3.34(1.17,9.19)$ & 0.000 & 79.9 & 0.007 & 4.98 & $3.35(1.11,9.58)$ & 0.000 & 78.9 & 0.009 & 4.75 \\
\hline Sheep & $6.19(3.77,10)$ & 0.000 & 5.0 & 0.349 & 1.06 & $3.33(1.74,6.28)$ & 0.000 & 0.0 & 0.462 & 0.78 \\
\hline Goats & $5.56(1.99,14.600)$ & 0.000 & 64.6 & 0.059 & 2.83 & $4.08(1.99,8.17)$ & 0.000 & 6,7 & 0.342 & 1.07 \\
\hline Pigs & $37.38(32.24,42.85)$ & 0.000 & 11.4 & 0.258 & 1.13 & $20.67(15.68,26.76)$ & 0.000 & 33.4 & 0.221 & 1.5 \\
\hline
\end{tabular}

$\mathrm{df}$, degrees of freedom; $I^{2}$, Inverse variance index; Q- $p$, probability value of Cochran's Q test; Z- $p$, probability value of Z test.

${ }^{\dagger}$ Slaughtered ruminants; all single study omitted pooled estimates were within the $95 \%$ confidence limits of the overall mean. 
Table 4 Frequencies (\%) of dominant serotypes

\begin{tabular}{|c|c|c|}
\hline Host, $n$, Authors & Serotype & Number (\%) \\
\hline \multirow[t]{7}{*}{ Cattle, $(n=69),[29-31]^{\ddagger}$} & S. Mishmarhaemek & $14(20.3)$ \\
\hline & S. Typhimurium & $12(17.4)$ \\
\hline & S. Newport & $9(13)$ \\
\hline & S. Eastbourne & $6(8.7)$ \\
\hline & S. Infantis & $5(7.3)$ \\
\hline & S. Anatum & $4(5.8)$ \\
\hline & Others & $19(27.5)$ \\
\hline \multirow[t]{5}{*}{ Small ruminants, $(n=55),[33,34]$} & S. Infantis & $15(27.3)$ \\
\hline & S. Typhimurium & $10(18.2)$ \\
\hline & S. Butantan & $8(14.6)$ \\
\hline & S. Heidelberg & $4(7.3)$ \\
\hline & Others & $18(32.7)$ \\
\hline \multirow[t]{6}{*}{ Pigs, $(n=267),[36,37]$} & S. Hadar & $85(31.8)$ \\
\hline & S. Eastbourne & $40(15)$ \\
\hline & S. Saintpaul & $37(13.9)$ \\
\hline & S. Kentucky & $20(7.5)$ \\
\hline & S. Typhimurium & $15(5.6)$ \\
\hline & Others & $70(26.2)$ \\
\hline \multirow[t]{6}{*}{ Camels, $(n=116),[38]$} & S. Saintpaul & $45(38.8)$ \\
\hline & S. Braenderup & $26(22.4)$ \\
\hline & S. Muenchen & $10(8.6)$ \\
\hline & S. Kottbus & $7(6)$ \\
\hline & S. Havana & $6(5.2)$ \\
\hline & Others & $22(19)$ \\
\hline
\end{tabular}

${ }^{\ddagger}$ The data excludes isolates from holding pens and hand swabs [30].

[33,36,37,59], S. Kottbus [36,56,59,62], S. Mishmarhaemek [29,31], S. Muenchen $[36,38,60,62], S$. Newport [30,31, 37,59], S. Saintpaul [36,38,55,57-59] and $S$. Typhimurium [29-31,33,34,36-38,56,57,59-62]. The occurrences of the serovars in different samples suggest their wide distribution across several animal populations and regions in Ethiopia. However, the relative preponderances and distributions of the serovars could differ by agro-climatic zones.

The preponderances of the serovars differ from reports elsewhere. For instance, in the USA, S. Newport (48.71\%), $S$. Agona (15.10\%) and S. Typhymurium (7.07\%) were the dominant isolates of bovine origin; $S$. Typhymurium (24.48\%), S. Derby (14.72\%) and S. Cholaraesuis (10.43\%) were the three most common isolates of porcine origin [63] and S. Oranienburg (21.8\%), S. Cerro (21.8\%) and $S$. Anatum $(10.3 \%)$ were the three most common isolates of beef cattle [42]. In Great Britain, $S$. Typhimurium (11.1\%), S. Derby (6.3\%) and $S$. Kedougou (0.9\%) were the top three serovars isolated from pigs [39]. In Korea, $S$. Typhimurium (47.6\%), S. Derby (20.6\%) and $S$. Heidelberg
(1.6\%) were the three top ranking isolates from swine samples [44].

Whilst four serovars were dominant in two or more host species, eleven were dominant in only a single host. $S$. Eastbourne was dominant in cattle and pigs; $S$. Infantis was dominant in cattle and small ruminants; $S$. Saintpaul was dominant in pigs and camels and $S$. Typhimurium was dominant in cattle, small ruminants and pigs. The differences in the relative occurrences of the serovars by host species could be due to differences in host-serovar interactions. The genetic make-ups of hosts could affect Salmonella [64] and a serotype may have different capabilities to infect different hosts [65]. Breed differences in the humoral and cell-mediated responses of pigs against $S$. Typhimurium were also reported [66,67]. Moreover, environmental factors may influence the survival of serovars/ strains and could possibly contribute to the within and between host species differences.

All serovars are generalists [68] and could be causes of outbreaks in humans and animals. Outbreaks associated with most of these serovars were recorded elsewhere. For instance, $S$. Braenderup, $S$. Infantis, $S$. Hadar, $S$. Heidelberg, S. Newport, $S$. Saintpaul, $S$. Typhimurium were causes of outbreaks that occurred between 2009 and 2014 in the USA [69]. Similarly, outbreaks due to $S$. Anatum in Japan [70], $S$. Kottbus in Spain [71], $S$. Eastbourne in Canada [72], $S$. Muenchen in Germany [73], S. Havana in Iran [74] and S. Kentucky in dairy cattle in the USA [75] were recorded. However, in Ethiopia, $S$. Typhimurium appears to be more important than others, because it was one of the dominant isolates in cattle, small ruminants and pigs (Table 4); it was isolated from camels [38] and animal products $[57,59,60]$ and accounted for $9.4 \%$ of the total and $15.3 \%$ of the NTS isolates of human origin [18]. Globally, S. Typhimurium represents $10-30 \%$ of the human NTS isolates [76] and in SSA it is a common cause of invasive infection $[16,77,78]$ with a high mortality in AIDS patients [79].

\section{Implications and limitations}

A national survey on the prevalence of Salmonella in Ethiopia has not been carried out. However the present study highlights the prevalence of carrier animals and the pooled estimates could be used as inputs in reenforcing the policy on meat safety in slaughter houses and butcheries and educating personnel in contact with animal products. Furthermore, regardless of the cultural taboos and the difficulties associated with the prohibition of backyard slaughtering, promoting educational campaigns to discourage the practice could reduce the risks of transmission of Salmonella from animals to man. In addition, although the economic stamina of the country and the infrastructure do not allow a nation-wide surveillance and 
monitoring of NTS, such systems and control measures could be implemented in high risk animal production systems (poultry, pigs and dairy cattle) because the number of such farms is very small.

Despite statistical evidences of heterogeneity, subgroup analyses were not done by potential risk factors but species. Moreover, pooled prevalence of Salmonella in dairy cattle and camels were not calculated because there are single reports on each. However, as the random effects model considers the studies as a sample of all potential studies, the estimates provide a relatively better picture of the occurrence of Salmonella and the comparative importance of food animals in Ethiopia.

\section{Conclusions}

All food animals are considerable reservoirs of Salmonella and at least 15 serotypes appear to be of considerable concerns. The results justify the need for strict intervention measures to reduce contamination of carcasses in slaughterhouses and the transmission of Salmonella from animals to humans. Large scale studies are required to describe the epidemiology of the serotypes in the country.

\section{Additional file}

Additional file 1: PRISMA check list.

Competing interests

The authors declare that they have no competing interests.

\section{Authors' contributions}

TG conceived the design, searched the literature, extracted the data, analyzed and interpreted the results and drafted the manuscript; TST revised the manuscript. Both authors read and approved the final manuscript.

\section{Acknowledgements}

We thank Dr. Bayleyegne Molla, Dr. Endrias Zewdu, Dr. Sefinew Alemu and Mr. Bayeh Abera for providing us with their articles.

\section{Author details}

${ }^{1}$ Department of Biomedical Sciences, College of Veterinary Medicine and Agriculture, Addis Ababa University, P.O. Box 34, Debra Zeit, Ethiopia. ${ }^{2}$ Institute of Biotechnology, College of Natural and Computational Sciences, Addis Ababa University, P.O. Box 1176, Addis Ababa, Ethiopia.

Received: 24 August 2014 Accepted: 15 October 2014

Published online: 15 November 2014

\section{References}

1. Majowicz SE, Musto J, Scallan E, Angulo FJ, Kirk M, O'Brien SJ, Jones TF, Fazil A, Hoekstra RM: The global burden of nontyphoidal Salmonella gastroenteritis. Clin Infect Dis 2010, 50:882-889.

2. Aarestrup FM, Hendriksen RS, Lockett J, Gay K, Teates K, McDermott PF: International spread of multidrug-resistant Salmonella Schwarzengrund in food products. Emerg Infect Dis 2007, 13:726-731.

3. Pezzoli L, Elson R, Little CL, Yip H, Fisher I, Yishai R: Packed with salmonella-investigation of an international outbreak of salmonella senftenberg infection linked to contamination of prepacked basil in 2007. Foodborne Pathog Dis 2008, 5:661-668.
4. Tauxe RV, Doyle MP, Kuchenmüller TT, Schlundt JJ, Stein CE: Evolving public health approaches to the global challenge of foodborne infection. Int J Food Microbiol 2010, 139:16-28.

5. Pui CF, Wong WC, Chai LC, Tunung R, Jeyaletchumi P, Noor Hidayah MS, Ubong A, Farinazleen MG, Cheah YK, Son R: Salmonella: a food borne pathogen- review. Int Food Res J 2011, 18:465-473.

6. Hoelzer K, Switt AIM, Wiedmann M: Animal contact as a source of human non-typhoidal salmonellosis-Review. Vet Res 2011, 42:34. doi:10.1186/ 1297-9716-42-34.

7. Baker MG: A recurring salmonellosis epidemic in New Zealand linked to contact with sheep. Epidemiol Infect 2007, 135:76-83.

8. Besser TE, Goldoft M, Pritchett LC, Khakhria R, Hancock DD, Rice DH, Gay JM, Johnson W, Gay CC: Multiresistant Salmonella Typhimurium DT104 infections of humans and domestic animals in the Pacific Northwest of the United States. Epidemiol Infect 2000, 124:193-200.

9. Lazarus R, Waghorn D, Nash C: Cutaneous Salmonella infection. Scand J Infect Dis 2007, 39:257-258.

10. Hendriksen SWM, Orsel K, Wagenaar JA, Miko A, van Duijkeren E: Animal to human transmission of Salmonella Typhimurium DT104A variant. Emerg Infect Dis 2004, 10:2225-2227.

11. Neto FOC, Filho PRA, Barrow P, Berchieri A: Sources of human non-typhoid salmonellosis: a review. Braz J Poult Sci 2010, 12:1-11.

12. Le Hello S, Hendriksen SR, Doublet B: International spread of an epidemic population of salmonella enterica serotype Kentucky ST198 resistant to ciprofloxacin. J Infect Dis 2011, 204:675-684.

13. Le Hello S, Bekhit A, Granier SA, Barua H, Beutlich J, Zajac M, Münch S, Sintchenko V, Bouchrif B, Fashae K, Pinsard JL, Sontag L, Fabre L, Garnier M, Guibert V, Howard P, Hendriksen RS, Christensen JP, Biswas PK, Cloeckaert A, Rabsch W, Wasy D, Doublet B, Weill FX: The global establishment of a highly fluoroquinolone resistant Salmonella enterica serotype Kentucky ST198 strain. Front Microbio/ 2013, 4:395. doi:10.3389/fmicb.2013.00395.

14. Hendriksen RS, Mikoleit M, Kornschober C, Rickert RL, Duyne SV, Kjelsø C, Hasman H, Cormican M, Mevius D, Threlfall J, Angulo FJ, Aarestrup FM: Emergence of multidrug-resistant Salmonella Concord infections in Europe and the United States in children adopted from Ethiopia, 2003-2007. Pediatr Infect Dis J 2009, 28:814-818.

15. Vanhoof R, Gillis P, Stévart O, Boland C, Vandenberg O, Fux F, Collard J, Bertrand S: Transmission of multiple resistant Salmonella Concord from internationally adopted children to their adoptive families and social environment: proposition of guidelines. Eur J Clin Microbiol Infect Dis 2012, 31:491-497.

16. Feasey NA, Dougan G, Kingsley RA, Heyderman RS, Gordon MA: Invasive non-typhoidal salmonella disease: an emerging and neglected tropical disease in Africa. Lancet 2012, 379:2489-2499.

17. Moher D, Liberati A, Tetzlaff J, Altman DG, The PRISMA Group: Preferred reporting items for systematic reviews and meta-analyses: the PRISMA statement. PLoS Med 2009, 6:e1000097. doi:10.1371/journal.pmed.1000097.

18. Tadesse G: Prevalence of human Salmonellosis in Ethiopia: a systematic review and meta-analysis. BMC Infect Dis 2014, 14:88. doi:10.1186/14712334-14-88.

19. Tricco AC, Ng CH, Gilca V, Anonychuk A, Pham B, Berliner S: Canadian oncogenic human papillomavirus cervical infection prevalence: Systematic review and meta-analysis. BMC Infect Dis 2011, 11:235. doi:10.1186/1471-2334-11-235.

20. Calvo-Muñoz I, Gómez-Conesa A, Sánchez-Meca J: Prevalence of low back pain in children and adolescents: a meta-analysis. BMC Pediatr 2013, 13:14. doi:10.1186/1471-2431-13-14.

21. Hurley JC: Lack of impact of selective digestive decontamination on pseudomonas aeruginosa ventilator associated pneumonia: benchmarking the evidence base. J Antimicrob Chemother 2011, 66:1365-1373.

22. Egger M, Davey Smith G, Schneider M: Bias in meta-analysis detected by a simple graphical test. BMJ 1997, 315:629-634.

23. Duval S, Tweedie R: Trim and fill: A simple funnel-plot-based method of testing and adjusting for publication bias in meta-analysis. Biometrics 2000, 56:455-463.

24. Galbraith RF: A note on graphical presentation of estimated odds ratios from several clinical trials. Stat Med 1988, 7:889-894.

25. Higgins JP, Thompson SG: Quantifying heterogeneity in a meta-analysis. Stat Med 2002, 21:1539-1558.

26. DerSimonian R, Laird N: Meta-analysis in clinical trials. Control Clin Trials 1986, 7:177-188. 
27. Yang Y, Li X, Zhou F, Jin Q, Gao L: Prevalence of drug-resistant tuberculosis in mainland china: systematic review and meta-analysis. PLoS One 2011, 6:e20343. doi:10.1371/journal.pone.0020343.

28. Gao L, Zhang L, Jin Q: Meta-analysis: prevalence of HIV infection and syphilis among MSM in China. Sex Transm Infect 2009, 85:354-358. doi:10.1136/sti.2008.034702

29. Alemayehu D, Molla B, Muckle A: Prevalence and antimicrobial resistance pattern of Salmonella isolates from apparently healthy slaughtered cattle in Ethiopia. Trop Anim Health Prod 2003, 35:309-319.

30. Sibhat B, Zewde BM, Zerihun A, Muckle A, Cole L, Boerlin P, Wilkie E, Perets A, Mistry K, Gebreyes WA: Salmonella serovars and antimicrobial resistance profiles in beef cattle, slaughterhouse personnel and slaughterhouse environment in Ethiopia. Zoonoses Public Hith 2011, 58:102-109.

31. Alemu S, Zewde BM: Prevalence and antimicrobial resistance profiles of Salmonella enterica serovars isolated from slaughtered cattle in Bahir Dar, Ethiopia. Trop Anim Health Prod 2012, 44:595-600.

32. Addis Z, Kebede N, Worku Z, Gezahegn H, Yirsaw A, Kassa T: Prevalence and antimicrobial resistance of Salmonella isolated from lactating cows and in contact humans in dairy farms of Addis Ababa: a cross sectional study. BMC Infect Dis 2011, 11:222. doi:10.1186/1471-2334-11-222.

33. Woldemariam E, Molla B, Alemayehu D, Muckle A: Prevalence and distribution of Salmonella in apparently healthy slaughtered sheep and goats in Debre Zeit, Ethiopia. Small Rumin Res 2005, 58:19-24.

34. Molla W, Molla B, Alemayehu D, Muckle A, Cole L, Wilkie E: Occurrence and antimicrobial resistance of Salmonella serovars in apparently healthy slaughtered sheep and goats of central Ethiopia. Trop Anim Health Prod 2006, 38:455-462.

35. Teklu A, Negussie H: Assessment of risk factors and prevalence of Salmonella in small ruminants and environment in an export abattoir, Modjo, Ethiopia. Am-Eurasian J Agric Environ Sci 2011, 10:992-999.

36. Aragaw K, Molla B, Muckle A, Cole L, Wilkie E, Poppe C, Kleer J, Hildebrandt G: The characterization of Salmonella serovars isolated from apparently healthy slaughtered pigs at Addis Ababa abattoir, Ethiopia. Prev Vet Med 2007, 82:252-261.

37. Molla B, Berhanu A, Muckle A, Cole L, Wilkie E, Kleer J, Hildebrandt G: Multidrug resistance and distribution of Salmonella serovars in slaughtered pigs. J Vet Med B Infect Dis Vet Public Health 2006, 53:28-33.

38. Molla B, Mohammed A, Salah W: Salmonella prevalence and distribution of serotypes in apparently healthy slaughtered camels (Camelus dromedarius) in eastern Ethiopia. Trop Anim Health Prod 2004, 36:451-458.

39. Davies RH, Dalziel R, Gibbens JC, Wilesmith JW, Ryan JMB, Evans SJ, Byrne C, Paiba GA, Pascoe SJS, Teale CJ: National survey for Salmonella in pigs, cattle and sheep at slaughter in Great Britain (1999-2000). J Appl Microbiol 2004, 96:750-760

40. Ishihara K, Takahashi T, Morioka A, Kojima A, Kijima M, Asai T, Tamura Y: National surveillance of Salmonella enterica in food-producing animals in Japan. Acta Vet Scand 2009, 51:35. doi:10.1186/1751-0147-51-35.

41. Fegan $N$, Vanderlinde $P$, Higgs $G$, Desmarchelier P: Quantification and prevalence of Salmonella in beef cattle presenting at slaughter. $J$ App Microbiol 2004, 97:892-898.

42. Dargatz DA, Fedorka-Cray PJ, Ladely SR, Ferris KE: Survey of Salmonella serotypes shed in feces of beef cows and their antimicrobial susceptibility patterns. J Food Prot 2000, 63:1648-1653.

43. Kim H, Baek H, Lee S, Jang Y, Jung S, Kim A, NongHoon Choe N: Prevalence and antimicrobial resistance of Salmonella spp. and Escherichia coli isolated from pigs at slaughterhouses in Korea. Afr $\mathrm{J}$ Microbiol Res 2011, 5:823-830.

44. Jung H, Lee S, Chiyoung K, Sunwoo S, Lyoo YS: Serovars distribution and antimicrobial resistance patterns of Salmonella spp. isolated from the swine farms and slaughter houses. Korean J Vet Res 2011, 51:123-128.

45. Käsbohrer A, Protz D, Helmuth R, Nockler K, Blaha T, Conraths F, Geue L: Salmonella in slaughter pigs of German origin: an epidemiological study. Eur J Epidemiol 2000, 16:141-146.

46. Hald T, Wingstrand A, Swanenburg M, von Altrock A, Thornberg B: The occurrence and epidemiology of Salmonella in European pig slaughterhouse. Epidemiol Infect 2003, 131:1187-1203.

47. European Food Safety Authority: Analysis of the baseline survey of Salmonella in holdings with breeding pigs, in the EU, 2008; Part B: Analysis of factors potentially associated with Salmonella pen positivity. EFSA J 2011, 9:2329. doi:10.2903/j.efsa.2011.2329.
48. Wegener HC, Hald T, Wong DLF, Madsen M, Korsgaard H, Flemming Bager F, Gerner-Smidt P, Mølbak K: Salmonella Control Programs in Denmark. Emerg Infect Dis 2003, 9:774-780.

49. Christensen J, Baggesen DL, Nielsen B, Stryhn H: Herd prevalence of Salmonella spp. in Danish pig herds after implementation of the Danish Salmonella control program with reference to a pre-implementation study. Vet Microbiol 2002, 88:175-188.

50. Ferede B: Isolation and identification of Salmonella, antimicrobial sensitivity and assessment of public awareness on the management of raw goat meat slaughtered at Diredawa municipal abattoir, Eastern Ethiopia. MSc thesis. Addis Ababa University, Microbiology, Immunology and Veterinary Public Health Department; 2014

51. Mekonnen H, Habtamu T, Kelali A, Shewit K: Food safety knowledge and practices of abattoir and butchery shops and the microbial profile of meat in Mekelle City, Ethiopia. Asian Pac J Trop Biomed 2013, 3:407-412.

52. Endale BG, Hailay G: Assessment of bacteriological quality of meat contact surfaces in selected butcher shops of Mekelle city, Ethiopia. J Environ Occup Sci 2013, 2:61-66.

53. Merritt TD, Herlihy C: Salmonella outbreak associated with chicks and ducklings at childcare centres. Med J Aust 2003, 179:63-64

54. Sanchez S, Hofacre CL, Lee MD, Maurer JJ, Doyle MP: Animal sources of salmonellosis in humans. J Am Vet Med Assoc 2002, 221:492-497.

55. Nyeleti C, Molla B, Hildebrandt G, Kleer J: The prevalence and distribution of Salmonellae in slaughter cattle, slaughterhouse personnel and minced beef in Addis Ababa (Ethiopia). Bull Anim Health Prod Afr 2000, 48:19-24.

56. Molla B, Mesfin A: A survey of Salmonella contamination in chicken carcass and giblets in central Ethiopia. Rev Médicin Vét 2003, 154:267-270.

57. Tibaijuka B, Molla B, Hildebrandt G, Kleer J, Salah W: Occurrence of Salmonellae in retail raw chicken products in Ethiopia. Berl Munch Tierarztl Wochenschr 2003, 116:55-58.

58. Ejeta G, Molla B, Alemayehu D, Muckle A: Salmonella serotypes isolated from minced meat beef, mutton and pork in Addis Ababa, Ethiopia. Rev Médicin Vét 2004, 155:547-551.

59. Zewdu E, Poppe C: Antimicrobial resistance pattern of Salmonella serotypes isolated from food items and personnel in Addis Ababa, Ethiopia. Trop Anim Health Prod 2009, 41:241-249.

60. Molla B, Kleer J, Sinell H: Occurrence, distribution and level of Salmonella in selected food items in Addis Ababa (Ethiopia). Fleischwirtschaft int 1999, 4:37-39.

61. Beyene G, Nair S, Asrat D, Mengistu Y, Engers H, Wain J: Multidrug resistant Salmonella Concord is a major cause of salmonellosis in children in Ethiopia. J Infect Dev Ctries 2011, 5:23-33.

62. Gebre-Yohannes A: Salmonella from Ethiopia: prevalent species and their susceptibility to drugs. Ethiop Med J 1985, 23:97-102.

63. Jackson CR, Fedorka-cray PJ, Wineland N, Tankson JD, Barrett JB, Douris A, Gresham CP, Jackson-hall C, Mcglinchey BM, Price MV: Introduction to United States Department of Agriculture VetNet: Status of Salmonella and Campylobacter Databases from 2004 Through 2005. Foodborne Pathog Dis 2007, 4:241-248.

64. Holt PS: Host Susceptibility, resistance and immunity to Salmonella in Animals. In Salmonella in Domestic Animals. Edited by Wray C, Wray A. Wallingford: CABI publishing; 2000:73-87.

65. Gast RK, Benson ST: The comparative virulence for chicks of Salmonella enteritidis phage type 4 isolates and isolates of phage types commonly found in poultry in the United States. Avian Dis 1995, 39:567-574.

66. Lacey C, Wilkie BN, Kennedy BW, Mallard BA: Genetic and other effects on bacterial phagocytosis and killing by cultured peripheral blood monocytes of SLA-defined miniature pigs. Animal Genet 1989, 20:371-381.

67. Lumsden JS, Kenndey BW, Mallard BA, Wilkie BN: The influence of the swine major histocompatibility genes on antibody and cell-mediated immune responses to immunization with an aromatic dependent mutant of Salmonella typhimurium. Can J Vet Res 1993, 57:14-18.

68. Uzzau S, Brown DJ, Wallis T, Rubino S, Leori G, Bernard S, Casadesus J, Plat DJ, Olsen JE: Host adapted serotypes of Salmonella enterica. Epidemiol Infect 2000, 125:229-255.

69. CDC: Reports of selected Salmonella outbreak investigations. Atlanta, GA: CDC; 2014 [http://www.cdc.gov/salmonella/outbreaks.html]

70. Ebuchi S, Baba A, Uryu K, Hiwaki H: Two outbreaks involving Salmonella Derby and S. Anatum at Grilled-meat restaurants in Fukuoka city. Jpn J Infect Dis 2006, 59:405-406. 
71. Palmera-Suárez R, García P, García A, Barrasa A, Herrera D: Salmonella Kottbus outbreak in infants in Gran Canaria (Spain), caused by bottled water, August -November 2006. Euro Surveill 2007, 12, E070712.2.

72. Craven PC, Mackel DC, Baine WB, Barker WH, Gangarosa EJ: International outbreak of Salmonella Eastbourne infection traced to contaminated chocolate. Lancet 1975, 5:788-792.

73. Buchholz U, Brodhun B, Brockmann SO, Dreweck CM, Prager R, Tschäpe H Ammon A: An outbreak of Salmonella München in Germany associated with raw pork meat. J Food Prot 2005, 68:273-276.

74. Backer HD, Mohle-Boetani JC, Werner SB, Abbott SL, Farrar J, Vugia DJ: High incidence of extra-intestinal infections in a Salmonella Havana outbreak associated with alfalfa sprouts. Public Health Rep 2000, 115:339-345.

75. Lu Z, Mitchell MR, Smith RL, Karns JS, van Kessel JAS, Wolfgang DR, Schukken YH, Grohn YT: Invasion and transmission of Salmonella Kentucky in an adult dairy herd using approximate Bayesian computation. BMC Vet Res 2013, 9:245. doi: 10.1186/1746-6148-9-245.

76. Helms M, Ethelberg S, Molbak K: International Salmonella Typhimurium DT104 infections, 1992-2001. Emerg Infect Dis 2005, 11:859-867.

77. Berkley JA, Lowe BS, Mwangi I, Williams T, Bauni E, Mwarumba S, Ngetsa C, Slack MP, Njenga S, Hart CA: Bacteremia among children admitted to a rural hospital in Kenya. N Engl J Med 2005, 352:39-47.

78. Gordon MA, Graham SM, Walsh AL, Phiri LW, Molyneux E, Zijlstra EE, Heyderman RS, Hart CA, Molyneux ME: Epidemics of invasive Salmonella enterica serovar Enteritidis and S. enterica serovar Typhimurium infection associated with multidrug resistance among adults and children in Malawi. Clin Infect Dis 2008, 46:963-969.

79. Fisk TL, Lundberg BE, Guest JL, Ray S, Barrett TJ, Holland B, Stamey K Angulo FJ, Farley MM: Invasive infection with multidrug-resistant Salmonella enterica serotype Typhimurium definitive type 104 among HIV-infected adults. Clin Infect Dis 2005, 40:1016-1021.

doi:10.1186/s12866-014-0270-y

Cite this article as: Tadesse and Tessema: A meta-analysis of the prevalence of Salmonella in food animals in Ethiopia. BMC Microbiology 2014 14:270

\section{Submit your next manuscript to BioMed Central and take full advantage of:}

- Convenient online submission

- Thorough peer review

- No space constraints or color figure charges

- Immediate publication on acceptance

- Inclusion in PubMed, CAS, Scopus and Google Scholar

- Research which is freely available for redistribution 